\title{
PENGARUH PERENCANAAN PAJAK, KEPEMILIKAN MANAJERIAL DAN UKURAN PERUSAHAAN TERHADAP PRAKTIK MANAJEMEN LABA
}

\author{
Enong Muiz ${ }^{1}$, Heni Ningsih ${ }^{2}$ \\ ${ }^{1}$ Universitas Muhammadiyah Prof. Dr. Hamka, enong@stiemj.ac.id \\ ${ }^{2}$ Universitas Muhammadiyah Prof. Dr. Hamka, heniningsih12@gmail.com
}

\begin{abstract}
ABSTRAK
Penelitian ini bertujuan untuk mengetahui pengaruh perencanaan pajak, kepemilikan manajerial dan ukuran perusahaan terhadap manajemen laba pada perusahaan manufaktur sub sektor otomotif dan komponen yang terdaftar di Bursa Efek Indonesia (BEI). Pengambilan sampel dalam penelitian ini menggunakan purposive sampling yaitu penetapan sampel berdasarkan kriteria tertentu maka sampel yang digunakan adalah 4 (empat) perusahaan manufaktur sub sektor otomotif dan komponen yang telah memenuhi kriteria yang sudah ditentukan.

Hasil dari penelitian ini menunjukkan bahwa secara parsial perencanaan pajak berpengaruh positif dan tidak signifikan terhadap manajemen laba sedangkan kepemilikan manajerial dan ukuran perusahaan berpengaruh positif dan signifikan terhadap manajemen laba. Namun, secara simultan perencanaan pajak, kepemilikan manajerial dan ukuran perusahaan berpengaruh positif dan signifikan terhadap manajemen laba. Dari hasil penelitian ini peneliti memberikan beberapa saran bagi penelitian selanjutnya untuk mendapatkan hasil yang lebih baik karena hasil yang didapatkan peneliti masih banyak kekurangan dan perlu dilakukan penelitian selanjutnya.

Kata Kunci : Perencanaan Pajak, Kepemilikan Manajerial, Ukuran Perusahaan dan Manajemen Laba
\end{abstract}

\section{ABSTRACT}

This study aims to determine the effect of tax planning, managerial ownership and company size on earnings management in the manufacturing companies of the automotive sub sector and components listed on the Indonesia Stock Exchange (IDX). Sampling in this study uses purposive sampling, namely the determination of samples based on certain criteria, the sample used is 4 (four) automotive sub sector manufacturing companies and components that have met the specified criteria. The results of this study indicate that partially tax planning has a positive and not significant effect on earnings management while managerial ownership and company size have a positive and significant effect on earnings management. However, simultaneous tax planning, managerial ownership and firm size have a positive and significant effect on earnings management. From the results of this study, researchers provide some suggestions for further research to get better results because the results obtained by researchers are still lacking and further research needs to be done.

Keywords: Tax Planning, Managerial Ownership, Company Size and Profit Management 


\section{JURNAL EKOBIS: EKONOMI, BISNIS \& MANAJEMEN} Volume 8 Nomor 2 (2018)

\section{PENDAHULUAN}

Laporan keuangan adalah alat terpenting yang digunakan sebagai bahan pengambilan keputusan oleh manajer dalam perusahaan. Laporan keuangan merupakan informasi akuntansi yang menggambarkan posisi keuangan perusahaan dan hasil usaha perusahaan pada suatu periode tertentu (Islahuzzaman, 2012 : 242). Pernyataan Standar Akuntansi Keuangan (PSAK) No. 1 tahun 2017 menjelaskan bahwa tujuan laporan keuangan adalah untuk memberikan informasi mengenai posisi keuangan, kinerja keuangan dan arus kas entitas yang bermanfaat bagi sebagian besar pengguna laporan keuangan dalam pembuatan keputusan ekonomi. Jumlah laba perusahaan merupakan informasi terpenting yang terdapat dalam laporan keuangan.

Laba merupakan gambaran hasil dari kegiatan usaha perusahaan, akan tetapi laba sering menjadi target rekayasa yang dilakukan pihak manajemen untuk meminimalkan atau memaksimalkan laba. Dengan kata lain, manajemen melakukan praktik manajemen laba (earning management). Manajemen laba adalah suatu tindakan yang mengatur laba sesuai dengan yang dikehendaki oleh pihak tertentu atau terutama oleh manajemen perusahaan. Tindakan manajemen laba sebenarnya didasarkan oleh berbagai tujuan yang terkandung didalamnya. Hal ini tidaklah aneh karena tingkat keuntungan atau laba yang diperoleh sering dikaitkan dengan prestasi manajemen disamping memang adalah suatu yang lazim bahwa besar kecilnya laba yang diperoleh (Irham Fahmi, 2014 : 519).

Salah satu contoh kasus yang terjadi di Indonesia yaitu kelompok usaha Ancora dituding merekayasa laporan keuangan dengan maksud untuk menghindari pembayaran pajak. Salah satu anak usaha yang diduga berusaha menghindari pajak adalah PT Ancora Mining Service dengan cara merekayasa laporan pembayaran bunga utang dan penerimaan dari sumbangan luar negeri. PT Ancora juga melaporkan ada pembayaran bunga utang padahal dalam neracanya tidak ditemukan adanya utang. Demikian juga dengan penerimaan dari sumbangan yang dilaporkan hanya untuk mengurangi pembayaran pajak.

Dokumen laporan keuangan yang diduga telah direkayasa adalah terbitan 31 Desember 2008. Nilai pembayaran bunga utang yang dilakukan sebesar Rp 18 Miliyar padahaltidak ada utang yang perlu dibayar. Selain itu, tercatat ada sumbangan sebesar 500.000 dollar AS yang diberikan perusahaan tambang Middle East Coal (MEC) merupakan perusahaan yang terpusat di Singapura dan Jakarta. Setelah itu, terdapat peningkatan jumlah anak perusahaan pada kelompok usaha Ancora ini menjadi 19 perusahaan. Hal itu mengindikasikan akanterjadi rekayasa terhadap laporan keuangan yang memungkinkan ada perbedaan harga jual produk antara induk perusahaan di satu negara dengan anak perusahaan di negara berbeda agar menurunkan kewajiban pajak.

Temuan sumbangan itu ditemukan Badan Pemeriksa Keuangan (BPK) yang mengindikasikan aliran dana dari $M E C$ ke yayasan milik kelompok usaha Ancora. Sumbangan ini mencurigakan karena tidak pernah dilaporkan pajak penerimaannya. MEC memiliki yayasan sendiri mengapa harus diserahkan pada yayasan milik Ancora. Kecurigaan lain juga muncul dalam laporan investasi Ancora. Dalam neraca tertanggal 31 Desember 2008 tidak ada laporan investasi yang dilakukan Ancora Mining Service. Namun, dalam laporan laba rugi dibukukan penghasilan senilai Rp 34,96 miliar (www.kompas.com, diakses pada tanggal 19 November 2017).

Menurut Scott (2014) mengemukakan faktor yang menyebabkan terjadinya manajemen laba yaitu bonus purposes, contracting motivation, to meet investor's earnings motivation, initial 


\section{JURNAL EKOBIS: EKONOMI, BISNIS \& MANAJEMEN}

public offering dan pentingnya memberi informasi kepadainvestor.

Terkait dengan hal diatas, pemerintah dalam tindakan mengurangi praktik manajemen laba yang dilakukan perusahaan terkait pemungutan pajak mengeluarkan aturan pelaksanaan ketentuan Peraturan Menteri Keuangan (PMK) yaitu PMK-238/PMK.03/2008. Pemerintah telah merevisi beberapa Undang-Undang (UU) perpajakan. Salah satunya adalah merevisi UU pajak penghasilan. UU PPh No. 36 tahun 2008 telah terjadi perubahan tarif pajak badan yang semula menganut sistem tarif pajak berlapis (10\%, 15\% dan 30\%) menjadi tarif tunggal yaitu sebesar $28 \%$ yang mulai berlaku efektif pada 1 Januari 2009 dan tarif $25 \%$ yang mulai berlaku efektif pada 1 Januari 2010 (Afriyanti, 2011).

Dalam teori keagenan (agency theory), hubungan antara principal dan agent mempunyai kepentingan yang berbeda. Dimana, principal mempunyai keinginan agar perusahaan dapat membayar pajak dengan sesuai.Sedangkan, agent lebih cenderung melakukan usaha meminimumkan beban pajak. Oleh karena itu, upaya yang dilakukan manajemen untuk memperoleh laba yaitu adanya perubahan tarif pajak badan dengan mengalokasikan laba tahun sebelum perubahan tarif pajak badan ke tahun sesudah perubahan tarif pajak. Dengan kata lain, memindahkan penghasilan bersih ke periode pajak yang tarifnya lebih rendah.

Diberlakukannya UU No. 36 tahun 2008 diharapkan memberi keringanan beban pajak bagi perusahaan tetapi perusahaan tetap menganggap pajak menjadi sebuah beban yang harus dibayarkan. Kondisi tersebut memicu pemerintah untuk melakukan perencanaan terhadap pajak agar perusahaan tidak dapat melakukan praktik manajemen laba. Perencanaan pajak (tax planning) adalah minimisasi penghasilan kena pajak dalam tahun berjalan dapat diinterpretasi sebagai maksimisasi penghasilan kena pajak di kemudian hari (Harnanto, 2013 : 19).

Suatu tax planning yang baik seharusnya tidak melanggar undang-undang dan peraturan perpajakan yang berlaku. Bila suatu tax planning ingin dipaksakan melanggar ketentuan perpajakan maka itu membuat wajib pajak merupakan resiko pajak yang sangat berbahaya dan mengancam keberhasilan perencanaan pajak. Secara bisnis dan masuk akal (reasonable) karena perencanaan pajak merupakan bagian yang tidak terpisahkan dari perencanaan menyeluruh perusahaan baik jangka pendek maupun jangka panjang maka perencanaan yang tidak masuk akal akan memperlemah perencanaan itu sendiri.

Pada umumnya, perencanaan pajak merujuk kepada proses merekayasa usaha transaksi wajib pajak agar utang pajak berada dalam jumlah yang minimal tetapi masih dalam bingkai peraturan perpajakan. Penelitian Ratna Eka Puji Astutik (2014), menunjukkan bahwa perencanaan pajak memiliki pengaruh positif terhadap manajemen laba di perusahaan manufaktur yang bergerak dalam bidang makanan dan minuman yang terdaftar di Bursa Efek Indonesia (BEI). Hal ini menunjukkan bahwa semakin baik perusahaan melakukan perencanaan pajak maka manajemen laba yang diterapkan dalam perusahaan juga semakin baik.

Penelitian tersebut berbeda dengan penelitian yang dilakukan oleh Ferry Aditama dan Anna Purwaningsih (2013), menunjukkan bahwa perencanaan pajak memiliki pengaruh negatif terhadap manajemen laba di perusahaan non- manufaktur yang terdaftar di Bursa Efek Indonesia (BEI). Hal ini menunjukkan bahwa kecilnya pengaruh perencanaan pajak terhadap manajemen laba pada perusahaan non-manufaktur dikarenakan oleh perusahaan nonmanufaktur kurang merespon penurunan tarif pajak dari $28 \%$ ke $25 \%$ yang mulai berlaku efektif tahun 2010 sehingga perusahaan non-manufaktur kurang siap dan kurang maksimal untuk menggeser periode biaya atau 
pendapatan.

Struktur kepemilikan menjadi penting dalam teori keagenan karena sebagian besar argumentasi konflik keagenan disebabkan oleh adanya pemisahan kepemilikan dan pengelolaan. Tidak jarang pihak manajemen yaitu manajer perusahaan mempunyai tujuan dan kepentingan lain yang bertentangan dengan tujuan utama perusahaan dan sering mengabaikan kepentingan pemegang saham. Perbedaan kepentingan antara manajer dan pemegang saham ini mengakibatkan timbulnya konflik yang biasa disebut agency conflict. Mekanisme yang dapat dilakukan untuk meredam konflik kedua belah pihak dengan cara menawarkan manajer bonus opsi saham dengan kata lain manajer akan menerima kompensasi berbasis saham.

Pemberian kompensasi untuk manajer akan mengakibatkan peningkatan kepemilikan manajerial. Kepemilikan manajerial adalah kepemilikan saham oleh pihak manajemen perusahaan. Kepemilikan saham manajerial dapat mensejajarkan antara kepentingan pemegang saham dengan manajer karena manajer ikut merasakan langsung manfaat dari keputusan yang diambil dan manajer yang menanggung resiko apabila ada kerugian yang timbul sebagai konsekuensi dari pengambilan keputusan yang salah. Kepemilikan manajerial memberikan kesempatan manajer terlibat dalam kepemilikan saham sehingga dengan keterlibatan ini kedudukan manajer sejajar dengan pemegang saham dan dapat meningkatkan kinerja manajer (Sugiarto, $2009: 80$ ).

Pada penelitian Puji Asih (2013), menunjukkan bahwa kepemilikan manajerial memiliki pengaruh positif terhadap manajemen laba di perusahaan manufaktur yang terdaftar di Bursa Efek Indonesia (BEI). Hal ini menunjukkan bahwa semakin besar kepemilikan manajerial yang dimiliki oleh manajer maka semakin tinggi pula praktik manajemen laba di perusahaan.

Penelitian tersebut berbeda dengan penelitian yang dilakukan oleh Frendy Sutikno, Wahidahwati dan Nur Fadjrih Asyik (2012), menunjukkan bahwa kepemilikan manajerial memiliki pengaruh negatif terhadap manajemen laba pada perusahaan perbankan Indonesia yang terdaftar di Bursa Efek Indonesia (BEI). Hal ini menunjukkan bahwa manajer memiliki porsi kepemilikan dan bertindak sama seperti pemegang saham dan memastikan bahwa laporan keuangan telah disajikan secara wajar sesuai kondisi rill perusahaan.

Ukuran perusahaan merupakan suatu indikator penting untuk mengetahui aktivitas operasional perusahaan yang lebih kompleks. Ukuran perusahaan menggambarkan besar kecilnya suatu perusahaan yang ditunjukkan oleh total aktiva, jumlah penjualan, rata-rata total penjualan dan rata-rata total aktiva. Perusahaan yang besar mendapat perhatian lebih dari pihak eksternal seperti investor, kreditor maupun pemerintah. Oleh karena itu, perusahaan yang berukuran besar lebih berhati-hati dalam melaporkan kondisi keuangannya. Sedangkan, perusahaan yang berukuran lebih kecil cenderung melakukan manajemen laba dengan melaporkan laba yang lebih besar untuk menunjukkan kinerja keuangan yang memuaskan (Makaombohe dkk, 2014 : 664).

Pada penelitian Frendy Sutikno, Wahidahwati dan Nur Fadjrih Asyik (2012), menunjukkan bahwa ukuran perusahaan memiliki pengaruh positif terhadap manajemen laba pada perusahaan perbankan Indonesia yang terdaftar di Bursa Efek Indonesia(BEI). Hal ini menunjukkan bahwa pada umumnya besar kecilnya total penjualan yang dimiliki perusahaan mengindikasikan besar kecilnya perusahaan berdampak terhadap manajemen laba yang dilakukan perusahaan dimana disebabkan oleh perusahaan besar cenderung lebih kecil melakukan tindakan manajemen laba dibandingkan perusahaan kecil. Penelitian tersebut berbeda dengan penelitian yang 
dilakukan oleh Sosiawan (2012), menun- jukkan bahwa ukuran perusahaan memiliki pengaruh negatif terhadap manajemen laba pada perusahaan manufaktur yang terdaftar di Bursa Efek Indonesia (BEI).Hal ini menunjukkan bahwa motivasi dewan direksi melakukan manajemen laba tidak didasarkan pada ukuran perusahaan.Adanya asimetri informasi yang berupa perolehan informasi dewan direksi lebih besar daripada informasi yang diterima oleh investor itu menjadi dasar motivasi tindakan manajemen laba oleh dewan direksi.

\section{METODE PENELITIAN}

Data yang digunakan dalam penelitian ini adalah data sekunder yang diambil dari laporan keuangan tahunan perusahaan manufaktur sub sektor otomotif dan komponen yang terdaftar di Bursa Efek Indonesia (BEI) pada tahun 2010-2017. Metode pengumpulan data dalam penelitian ini adalah kuantitatif. Metode kuantitatif adalah metode penelitian yang berlandaskan pada filsafat positivisme, digunakan untuk meneliti populasi atau sampel tertentu sebagai upaya untuk memperoleh data yang valid (Sugiyono, 2012:57). Penarikan sampel tersebut menggunakan purposive sampling yang merupakan pengambilan sampel secara sengaja sesuai dengan persyaratan atau kriteria sampel yang diperlukan. Data diperoleh dari data yang diterbitkan oleh Bursa Efek Indonesia (BEI). Operasionalisasi variabel yang digunakan adalah variabel independen (bebas) dan variabel dependen (terikat). Pada penelitian ini variabel dependen $(\mathrm{Y})$ adalah praktik manajemen laba dengan rumus sebagai berikut:

1. Menghitung nilai Total Akrual(TA) merupakan selisih dari pendapatan bersih (net income) dengan arus kas operasi untuk setiap perusahaan dan setiap tahun pengamatan. Rumusnya sebagai berikut:

\section{TAit $=$ Nit - CFOit}

Keterangan :

TAit $=$ Total akrual. Nit $=$ Net income.

CFOit $=$ Cash flows from operation .

2 Dengan menggunakan koefisien regresi diatas nilai Non Discretionary Accruals (NDA). Rumusnya sebagai berikut:

$$
\begin{aligned}
& \text { NDAit }=\square_{1}\left(\text { 1/Ait-1) }+\square_{2}(\square \text { REVt }-\right. \\
& \square \text { RECt/Ait-1) }+\square_{\mathbf{3}} \text { (PPEt/Ait-1) }+\square \\
& \text { Keterangan : } \\
& \text { NDAit = Non discretionary accruals } \\
& \text { perusahaan i pada periode } t \text {. } \\
& \beta_{1,} \beta_{2,} \beta_{3}=\text { Slope untuk perusahaan i pada periode } t \text {. } \\
& \text { Ait-1 = Total aktiva perusahaan i pada periode } \mathrm{t}-1 \text {. } \\
& \square \text { Revt }=\text { Perubahan pendapatan } \\
& \text { perusahaan i pada periode } \mathrm{t} \text {. } \\
& \square \text { Rect } \quad=\text { Perubahan piutang perusahaan i pada periode } \mathrm{t} \text {. } \\
& \text { PPEt = Aktiva tetap perusahaan pada periode } \mathrm{t}
\end{aligned}
$$


3. Dengan Discreationary Accruals (DA). Rumusnya sebagai berikut:

DTAit $=($ TAit $/$ Ait -1$)-($ NDAit $)$

Keterangan :

DTAit = Discretionary total accruals

perusahaan i pada periode $t$.

TAit = Total akrual perusahaan i pada periode $\mathrm{t}$.

Ait-1 = Total aktiva perusahaan i pada periode $\mathrm{t}-1$.

NDAit $=$ Non discretionary accruals

perusahaan i pada periode $t$.

Sedangkan variabel independen $(\mathrm{X})$ yang terdiri dari :

1. Perencanaan pajak $\left(\mathrm{X}_{1}\right)$ menggunakan rumus sebagai berikut:

TAXPLAN $=\square$ (TPt $x$ PTI"CTE)

\section{TAt}

Keterangan :

TAX PLAN= Perencanaan pajak.

$P T I=$ Pre-tax income (Laba sebelum kena pajak).

CTE = Current portion of total tax expance(Beban pajak kini).

$\mathrm{TP}=$ Tarif pajak $(25 \%)$

TA $=$ Total asset

2. Kepemilikan manajerial $\left(\mathrm{X}_{2}\right)$ menggunakan rumus sebagai berikut:

$\mathrm{KM}=\underline{\mathrm{SM}} \times \mathbf{1 0 0} \%$

SB

Keterangan :

$$
\begin{aligned}
\mathrm{KM}= & \text { Kepemilikan manajerial. } \\
\mathrm{SM}= & \text { Jumlah saham yang dimiliki } \\
& \text { manajerial. } \\
\mathrm{SB}= & \text { Jumlah saham yang beredar. }
\end{aligned}
$$

3. Ukuran perusahaan $\left(\mathrm{X}_{3}\right)$ menggunakan rumus sebagai berikut:

$$
\text { Size }=\operatorname{Ln}(\text { TA })
$$

Keterangan :

$$
\begin{array}{ll}
\log = & \text { Logaritma } \\
\mathrm{TA} & =\text { Total aset }
\end{array}
$$

Menurut Sugiyono (2014:80), populasi adalah wilayah generalisasi suatu obyek/subyek yang mempunyai kualitas dan karakteristik tertentu yang ditetapkan oleh peneliti untuk dipelajari dan kemudian ditarik kesimpulannya. Populasi dalam penelitian ini adalah seluruh perusahaan manufaktur sub sektor otomotif dan komponen yang terdaftar di Bursa Efek 
Indonesia (BEI) dari tahun 2010- 2017 dengan tujuan mengetahui bagaimana caranya pihak manajemen melakukan praktik manajemen laba di suatu perusahaan manufaktur sub sektor otomotif dan komponen.

Menurut Sugiyono (2014:81), sampel adalah bagian dari jumlah dan karakteristik yang dimiliki oleh populasi tersebut. Metode yang digunakan dalam penelitian ini adalah purposive sampling yaitu pengambilan sampel secara sengaja sesuai dengan persyaratan atau kriteria sampel yang diperlukan.

Dibawah ini populasi dari perusahaan manufaktur subsektor otomotif dan komponen di BEI sebagai berikut :

Tabel 1. Daftar Perusahaan Manufaktur Sub-Sektor Otomotif dan Komponen yang Terdaftar di Bursa Efek Indonesia (BEI)

\begin{tabular}{|c|c|c|}
\hline No & Nama Perusahaan & Kode Emiten \\
\hline 1. & Astra International Tbk. & ASII \\
\hline 2. & Astra Otoparts Tbk. & AUTO \\
\hline 3. & Garuda Metalindo Tbk. & BOLT \\
\hline 4. & Indo Kordsa Tbk. & BRAM \\
\hline 5. & Goodyear Indonesia Tbk. & GDYR \\
\hline 6. & Gajah Tunggal Tbk. & GJTL \\
\hline 7. & Indomobil Sukses International Tbk. & IMAS \\
\hline 8. & Indospring Tbk. & INDS \\
\hline 9. & Multi Prima Sejahtera Tbk. & LPIN \\
\hline 10. & Multistrada Arah Sarana Tbk. & MASA \\
\hline 11. & Nipress Tbk. & NIPS \\
\hline 12. & Prima Alloy Steel Universal Tbk. & PRAS \\
\hline 13. & Selamat Sempurna Tbk. & SMSM \\
\hline 14. & Bintang Oto Global Tbk. & BOGA \\
\hline
\end{tabular}

Sumber : http://idx.com, 2018.

Adapun beberapa kriteria dari sampel yang akan diambil untuk penelitian ini sebagai berikut: 
Tabel 2. Kriteria Sampel Penelitian

\begin{tabular}{|c|c|c|}
\hline No & Deshripsi & Jumlah Populasi \\
\hline 1. & $\begin{array}{l}\text { Perusahaan manufaktur sub sektor otomotif dan } \\
\text { komponen yang terdaftar di Bursa Efek Indonesia } \\
\text { (BEI) secara berturut-turut selama tahun } 2010-2017 \text {. }\end{array}$ & 14 \\
\hline 2. & $\begin{array}{l}\text { Perusahaan manufaktur sub sektor otomotif dan } \\
\text { komponen yang tidak menyajikan laporan kevangan } \\
\text { tahmnan (annual report) yang sudah di avdit selama } \\
\text { tahun 2010-2017. }\end{array}$ & (6) \\
\hline 3. & $\begin{array}{l}\text { Pervaahaan manufaktur sub sektor otomotif dan } \\
\text { komponen yang menyajikan pivtang dalam bentuk } \\
\text { dollar selama tahnn } 2010-2017 \text {. }\end{array}$ & (2) \\
\hline 4. & $\begin{array}{l}\text { Perusahaan manufaktur sub sektor otomotif dan } \\
\text { komponen yang mengalami rugi fiskal selama tahun } \\
2010-2017 \text {. }\end{array}$ & (2) \\
\hline & Jumlah Sampel & 4 \\
\hline & Jumlah Sampel yaitu $4 \times 8$ tahun & 32 \\
\hline
\end{tabular}

Sumber : Diolah oleh peneliti, 2018.

Berdasarkan pemilihan sampel, data yang diperoleh sebanyak 4 perusahaan manufaktur sub sektor otomotif dan komponen yang terdaftar di Bursa Efek Indonesia (BEI) selama 8 (delapan) tahun periode 2010-2017 menjadi 32 data.

Berikut ini perusahaan manufaktur sub sektor otomotif dan komponen yang menjadi sampel sebagai berikut:

Tabel 3. Daftar Sampel Penelitian

\begin{tabular}{|c|c|c|}
\hline No & Nama Perusahaan & Kode Emiten \\
\hline 1. & Astra International Tbk. & ASII \\
\hline 2. & Astra Otoparts Tbk. & AUTO \\
\hline 3. & Indospring Tbk. & INDS \\
\hline 4. & Selamat Sempurna Tbk. & SMSM \\
\hline
\end{tabular}

Sumber : Diolah oleh peneliti, 2018.

Data yang dianalisis dalam penelitian ini berkaitan dengan hubungan antar variabel 
penelitian. Peneliti melakukan proses analisis data dengan menggunakan analisis akuntansi dan program Software Program Service Solution (SPSS) versi 20.

\section{HASIL DAN PEMBAHASAN}

Pada penelitian ini, teknik analisis data menggunakan analisis regresi linear berganda.Analisis regresi linier berganda dilakukan untuk mengetahui hubungan antara variabel dependen dengan variabel independen dengan melihat hasil dari persamaan regresi dari seluruh data sampel yang telah diolah di SPSS versi 20tahun 2010-2017. Hasil olah data analisis regresi linier berganda dapat dilihat pada tabel berikut:

Tabel 4. Analisis Regresi Linier Berganda

\begin{tabular}{|l|r|r|}
\hline \multirow{2}{*}{ Model } & \multicolumn{2}{|c|}{$\begin{array}{c}\text { Unstandardized } \\
\text { Coefficients }\end{array}$} \\
\cline { 2 - 3 } & \multicolumn{1}{|c|}{ B } & \multicolumn{1}{|c|}{ Std. Error } \\
\hline \multirow{2}{*}{ (Constant) } & 7806502, & 1023040,3 \\
& 799 & 16 \\
1 & 12,212 & 7,521 \\
$\begin{array}{l}\text { Perencanaan } \\
\text { Pajak }\end{array}$ & 5,468 & 2,119 \\
$\begin{array}{l}\text { Kepemilikan } \\
\text { Manajerial }\end{array}$ &, 490 &, 077 \\
\hline $\begin{array}{l}\text { Ukuran } \\
\text { Perusahaan }\end{array}$ & \\
\hline
\end{tabular}

Sumber:Output SPSS versi 20, 2018.

Berdasarkan hasil tabel coefficients ${ }^{a}$, dapat kita dilihat pada kolom unstandardized coefficients pada kolom B diperoleh persamaan regresinya sebagai berikut :

$Y=-7.806 .502,799+12,212 X_{1}+5,468 X_{2}+0,490 X_{3}$.

Dari persamaan regresi linier berganda tersebut dapat diinterpretasikan sebagai berikut:

1. Nilai konstanta sebesar $-7.806 .502,799$ artinya apabila perencanaan pajak $\left(\mathrm{X}_{1}\right)$, kepemilikan manajerial $\left(\mathrm{X}_{2}\right)$ dan ukuran

perusahaan $\left(\mathrm{X}_{3}\right)$ nilainya 0maka nilai

manajemen laba (Y) menurun sebesar Rp

7.806.502,799 (dalam Jutaan)

2. Nilai koefisien regresi variabel perencanaan pajak $\left(X_{1}\right)$ bernilai positif sebesar 12,212 artinya apabila perencanaan pajak $\left(\mathrm{X}_{1}\right)$ mengalami kenaikan sebesar $\mathrm{Rp} 1$ dan variabel kepemilikan manajerial $\left(\mathrm{X}_{2}\right)$ dan ukuran perusahaan $\left(\mathrm{X}_{3}\right)$ dianggap konstan maka variabel manajemen 
laba (Y) akan mengalami kenaikan sebesar Rp 12,212 (dalam Jutaan).

3. Nilai koefisien regresi variabel kepemilikan manajerial $\left(\mathrm{X}_{2}\right)$ bernilai positif sebesar 5,468 artinya apabila kepemilikan manajerial $\left(\mathrm{X}_{2}\right)$ mengalami kenaikan sebesar $\mathrm{Rp} 1$ dan variabel perencanaan pajak $\left(\mathrm{X}_{1}\right)$ dan ukuran perusahaan $\left(\mathrm{X}_{3}\right)$ dianggap konstan maka variabel manajemen laba(Y) akan mengalami kenaikan sebesar Rp 5,468 (dalam Jutaan).

4. Nilai koefisien regresi variabel ukuran perusahaan $\left(X_{3}\right)$ bernilai positif sebesar 0,490 artinya apabila ukuran perusahaan $\left(\mathrm{X}_{3}\right)$ mengalami kenaikan sebesar $\mathrm{Rp} 1$ dan variabel perencanaan pajak $\left(\mathrm{X}_{1}\right)$ dan kepemilikan manajerial $\left(\mathrm{X}_{2}\right)$ dianggap konstan makavariabel manajemen laba (Y) akan mengalami kenaikan sebesar Rp 0,490 (dalam Jutaan).

Tabel 5. Uji Statistik T

\begin{tabular}{|c|c|c|c|}
\hline \multicolumn{2}{|c|}{ Model } & T & Sig. \\
\hline \multirow{7}{*}{1} & (Constant) & $-7,631$ &, 000 \\
\hline & Perencanaan & & \\
\hline & Pajak & 1,024 & 更 \\
\hline & Kepemilikan & 0 & 015 \\
\hline & Manajerial & 2,001 & 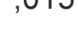 \\
\hline & Ukuran & & \\
\hline & Perusahaan & & \\
\hline
\end{tabular}

Berdasarkan hasil tabel coefficients ${ }^{a}$, dapat kita dilihat pada kolom $T$ dan kolom Sig. bahwa sebagai berikut:

1. Perencanaan pajak $\left(\mathrm{X}_{1}\right)$ memiliki $\mathrm{t}_{\text {hitung }}$ sebesar $1,624<\mathrm{t}_{\text {tabel }}$ sebesar 2,048 dan nilai signifikansi 0,116 dimana nilai signifikansi

$0,116>0,050$ yang berarti bahwa nilai perencanaan pajak berpengaruhpositif dan tidak signifikan terhadap manajemen laba.

2. Kepemilikan manajerial $\left(\mathrm{X}_{2}\right)$ memiliki thitung sebesar 2,581 $>\mathrm{t}_{\text {tabel }}$ sebesar 2,048 dan nilai signifikansi $0,015<0,050$ yang berarti bahwa nilaikepemilikanmanajerialberpengaruhpositif dan signifikan terhadap manajemen laba.

3. Ukuran perusahaan $\left(X_{3}\right)$ memiliki thitung sebesar 6,329 $>t_{\text {tabel }}$ sebesar 2,048 dan nilai signifikansi $0,000<0,050$ yang berarti bahwa nilai ukuran perusahaan berpengaruh positif dansignifikan terhadap manajemen laba. 
Tabel 6. Uji Pengaruh Simultan F

\begin{tabular}{|c|c|c|}
\hline Model & $F$ & Sig. \\
\hline $1 \begin{array}{l}\text { Regression } \\
\text { Residual } \\
\text { Total }\end{array}$ & 16,386 &, $000^{\mathrm{b}}$ \\
\hline
\end{tabular}

Sumber : Output SPSS versi 20, 2018.

Berdasarkan hasil tabel model summary ${ }^{b}$, dapat kita dilihat pada kolom Adjusted $R$ Square bahwa diperoleh nilai sebesar 0,598 yang berarti semakin besar atau terdapat pengaruh hubungan antara perencanaan pajak, kepemilikan manajerial dan ukuran perusahaan terhadap manajemen laba atau sebaliknya. Lalu nilai Adjusted $R$ Square yang berarti variansi atau naik turunnya nilai manajemen laba, 59,8 disebabkan oleh naik kepemilikan independen, komite audit, ukuran dewan, kepemilikan institusional, nilai laba bersih per saham, rasio pendapatan harga dan CEO duality. independen, komite audit, ukuran dewan, kepemilikan institusional, nilai laba bersih per saham, rasio pendapatan harga dan CEO duality.

\section{PENUTUP}

Hasil penelitian menunjukkan bahwa perencanaan pajak berpengaruh positif dan tidak signifikan terhadap manajemen laba. Kepemilikan manajerial berpengaruh positif dan signifikan terhadap manajemen laba. Ukuran perusahaan berpengaruh positif dan signifikan terhadap manajemen laba.

Berdasarkan hasil penelitian variabel perencanaan pajak menggunakan analisis akuntansi dan program Software Program Service Solution (SPSS) versi 20 mendapatkan hasil yang berbeda. Hal ini dapat terjadi karenapemerintah sangat membutuhkan biaya untuk membiayai kegiatan operasional dan pembangunan negara dari beban pajak yang masyarakat sudah setorkan ke kantor pajak. Disisi lain, manajer menganggap pajak merupakan suatu beban yang wajib dibayarkan sehingga manajer mengatur dan mengelola laba supaya dapat membayar pajak sekecil mungkin dan mendapatkan keuntungan sehingga diharapkan pada penelitian selanjutnya dapat menambahkan sampel agar penelitian selanjutnya mendapatkan hasil yang lebih maksimal.

Diharapkan kepada perusahaan yang memiliki aset banyak untuk mengatur asetnya lebih baik lagi dan memperkuat keamanan karena perusahaan yang memiliki aset banyak dapat memicu terjadinya perekayasaan laporan keuangan yang dilakukan oleh manajer. Diharapkan penelitian ini bisa memberikan masukan dan pertimbangan bagi perusahan- perusahaan manufakturyang terdaftar di Bursa Efek Indonesia (BEI) untuk menyajikan laporan keuangan secara wajar dan dapat memberikan informasi yang akurat maupun relevan serta terbebas dari adanya kecurangan yang akan sangat menyesatkan para pengguna laporan keuangan dalamproses pengambilan keputusan. Untuk 
penelitian selanjutnya diharapkan dapat memperluas objek penelitian untuk meneliti aspek-aspek lain yang dapat mempengaruhi praktik manajemen laba sehingga akan tercapai hasil penelitian yang lebih baik.

\section{REFERENSI}

Afriyanti Y. (2011). Analisis Respon Wajib Pajak Terhadap Pemberlakuan Undang-Undang Pajak Penghasilan Tahun 2008. Skripsi.Jakarta : Prodi Akuntansi Fakultas Ekonomi dan Bisnis Universitas Pembangunan Nasional Veteran.

AgusR. Sartono. (2010). Manajemen Keuangan Teori dan Aplikasi.Edisi 4.Yogyakarta : BPFE. Amah Kalu Ogbonnaya, Michael Chidiebere Ekwe, and John Uzoma Ihendinihu.(2016). The Influence of Corporate Governance Structure and Ownership Structure against on Earning Management Brewery Industry (On a Nigerian Company Company listed on the Nigerian Stock Exchange). European Accounting Journal, Audit and

Financial Research: Vol. 4, No. 7, (published by the European Research and Development Research Center of England in August 2016), pp: 35-45, ISSN : 2054-

6319 (print), ISSN : 2054-6327.Nigeria : Study Program Accounting Faculty of Economics and BusinessAgricultural University of Michael Okpara, Umudike, Nigeria.

Bambang Riyanto. (2010). Dasar-dasar Pembelanjaan Perusahaan.Cetakan 10.Yogyakarta : BPFE.

Budi Susilo. (2010). Pengaruh Kepemilikan Manajerial, Proporsi Dewan Komisaris Independen, Jumlah Komite Audit dan Keahlian Komite Audit terhadap Manajemen Laba (Pada Perusahaan Manufaktur yang terdaftar di Bursa Efek Indonesia (BEI)).Skripsi.Jakarta : Prodi Akuntansi Fakultas Ekonomi dan Bisnis Universitas Islam Negeri Syarif Hidayatullah.

Bringham, Eugene F. dan Houston Joel F. (2010).Dasar-dasar Manajemen Keuangan.Edisi 11 Indonesia.Buku 1.Jakarta: Salemba Empat.

Chairil Anwar Pohan. (2015). Manajemen Perpajakan.Edisi Revisi. Jakarta: Gramedia Pustaka Utama.

Dwi Martani., dkk. (2012). Akuntansi Keuangan Menengah Berbasis PSAK.Buku 1.Jakarta: Salemba Empat.

\section{Salemba Empat.}

Egbunike Amaechi Patrick, Ezelibe Chizoba Paulinus, and Aroh Nkechi Nympha. (2015).The Effect of Good Corporate Governance on Earnings Management (Companies registered in Nigeria). American Economic Journal, Finance and Management: Vol. 1, No. 5, (December 2015), pp: 482-493.Nigeria : Study Program Accounting Faculty of Economics and Businessat Nnamdi University Azikiwe Awka, State of Anambra, Nigeria and the Federal Polytechnic of Oko, Anambra State, Nigeria.

Enong Muiz. (2011). Buku Ajar Perencanaan Pajak.Buku 2.Jakarta: Uhamka Press.

Erly Suandy. (2016). Perencanaan Pajak.Edisi 6.Jakarta: Salemba Empat.

Eva Rafika Dewi, Elva Nuraina,dan Nik Amah. (2016). Pengaruh Tax Planning dan Ukuran Perusahaan terhadap Manajemen Laba (Pada Perusahaan Property yang 


\section{JURNAL EKOBIS: EKONOMI, BISNIS \& MANAJEMEN}

Volume 8 Nomor 2 (2018)

terdaftar di Bursa Efek Indonesia.Jurnal The 9th FIPA: Forum Ilmiah Pendidikan Akuntansi : Volume. 5, No. 1, (Oktober 2017), hlm : 854-881, ISSN: 2337 -

9723.Madiun : Prodi Pendidikan Akuntansi Fakultas Keguruan Ilmu Pengetahuan Universitas Persatuan Guru Republik Indonesia (PGRI) Madiun.

Ferry Aditama dan Anna Purwaningsih. (2013). Pengaruh Perencanaan Pajak terhadap Manajemen Laba (Pada Perusahaan Nonmanufaktur yang terdaftar di Bursa Efek Indonesia (BEI)). Jurnal Modus : Volume. 26, No. 1, (Desember 2013), hlm: 33-50, ISSN:0852-1875. Yogyakarta : Prodi Akuntansi Fakultas Ekonomi dan Bisnis Universitas Atma Jaya Yogyakarta.

Frendy Sutikno, Wahidahwati, dan Nur Fadjrih Asyik. (2012). Pengaruh Corporate Governance dan Ukuran Perusahaan terhadap Manajemen Laba pada Perusahaan Perbankan di Indonesia.Jurnal Ilmu dan Riset Akuntansi Volume.3, No. 10, Desember 2014.Surabaya : Prodi Akuntansi Fakultas Ekonomi dan Bisnis Sekolah Tinggi Ilmu Ekonomi Indonesia (STIESIA) Surabaya.

Hanafi, Mahmud M. (2014). Manajemen Keuangan. Cetakan kelima.Yogyakarta : BPFE. dan Abdul Halim. (2014). Analisis Laporan Keuangan. Edisi Tujuh.

Yogyakarta : UPP. AMP YKPN.

Harahap, Sofyan S. (2013). Analisis Kritis Atas Laporan Keuangan.Jakarta :Rajawali.

Harnanto.(2013). Perencanaan Pajak. Edisi Pertama. Yogyakarta : BPFE.

Ikatan Akuntan Indonesia.(2017). Standar Akuntansi Keuangan Efektif per 1 Januari 2017.Jakarta : Ikatan Akuntan Indonesia.

Imam Ghozali. (2011). Aplikasi Analisis Multivariate Dengan Program SPSS.Semarang : Badan Penerbit Universitas Diponegoro. (2013). Aplikasi Analisis Multivariate Dengan Program SPSS. Edisi Ketujuh.

Semarang : Badan Penerbit Universitas Diponegoro.

Irham Fahmi. (2013). Pengantar Manajemen Keuangan.Bandung : Alfabeta. . (2014). Manajemen Keuangan Perusahaan dan Pasar Modal.Bandung : Alfabeta. . (2014). Analisis Laporan Keuangan.Bandung : Alfabeta.

Islahuzzaman.(2012). Istilah-istilah Akuntansi dan Auditing. Edisi Kesatu. Jakarta : Bumi Aksara. Izza Kumala. (2015). Pengaruh Corporate Governance, Ukuran Perusahaan dan Leverage terhadap Earning Management (Pada Perusahaan Manufaktur Sub Sektor Food and Beverage yang terdaftar di Bursa Efek Indonesia (BEI)).Skripsi. Jawa Timur : Prodi Akuntansi Fakultas Ekonomi dan Bisnis Universitas Muhammadiyah Sidoarjo.

Kasmir.(2012). Analisis Laporan Keuangan.Jakarta : Raja Grafindo Persada. Makaombohe, Yuliati Y., Sifrid S.P., dan Victorina

Z.T. (2014). Pengaruh Ukuran Perusahaan terhadap Manajemen Laba pada Perbankan yang terdaftar di Bursa Efek Indonesia periode 2008-2011. Jurnal EMBA, Volume. 2 No. 1, hal.656-665, Maret 2014.Manado : Prodi Akuntansi Fakultas Ekonomi dan Bisnis Universitas Sam Ratulangi Manado.

Mauliridiyah Sevilia Putri dan Farida Titik Dra.(2013). Pengaruh Kepemilikan Manajerial, Leverage dan Ukuran Perusahaan terhadap Manajemen laba pada Perusahaan Food and Beverage.Jurnal e-Proceeding of Management, Volume. 1, No. 3, Desember

2014, ISSN :2355-9357. Bandung : Prodi Akuntansi Fakultas Ekonomi dan Bisnis 
Universitas Telkom Bandung.

MehmetAygun, SuleymanIc,and MustafaSayim. (2014). The Effects of Corporate Ownership Structure and Board Size on Earnings Management: Evidence from Turkey. International Journal of Business and Management : Vol. 9, No. 12, December 2014, ISSN : 1833-3850 E-

ISSN : 1833-8119. Turkey : Study Program Management Faculty of Economics and Administration and AlliantYüzüncü Yil Van University, Mayis SamsunUniversity: Turkey and University San Diego: CA.

Muhammad Zain. (2010). Manajemen Perpajakan.Jakarta : Salemba Empat.

Mursyidi. (2010). Akuntansi Biaya : Conventional Costing, Just In Time, Activity-Based Costing. Bandung : Refika Aditama.

Puji Asih. (2013). Faktor-Faktor yang Mempengaruhi Praktek Manajemen Laba.Jurnal Telaah Akuntansi dan Bisnis.Volume. 5, No. 02, September 2013, hlm : 191-201.Jakarta : Prodi Akuntansi Fakultas Ekonomi dan Bisnis Universitas Mercu Buana.

Ratna Eka, Puji A. (2014). Pengaruh Perencanaan Pajak dan Beban Pajak angguhan terhadap Manajemen Laba. Jurnal Ilmu dan Riset Akuntansi Volume.5, No. 3, Maret 2014. Surabaya : Prodi Akuntansi Fakultas Ekonomi dan Bisnis Sekolah Tinggi Ilmu Ekonomi Indonesia (STIESIA) Surabaya.

Republik Indonesia.(2008). Undang-Undang Republik Indonesia No. 20 Tahun 2008 Tentang Usaha Mikro, Kecil dan Menengah.Indonesia: Undang-Undang Republik Indonesia.

Republik Indonesia. (2008).Undang-Undang Republik Indonesia No. 36 Tahun 2008 dalam Pasal 17 dan Pasal 31E ayat (1) Tentang Pajak Penghasilan (PPh). Indonesia : UndangUndang Republik Indonesia.

Republik Indonesia.(2008). Peraturan Menteri Keuangan Republik Indonesia PMK-238/ PMK.03/2008 Tentang Tata Cara Pelaksanaan Dan Pengawasan Pemberian Penurunan Tarif Bagi Wajib Pajak Badan Dalam Negeri Berbentuk Perseroan Terbuka.Indonesia : Peraturan Menteri Keuangan Republik Indonesia.

Riduwan dan Sunarto.(2013). Pengantar Statistika untuk Penelitian Pendidikan Sosial, Ekonomi, Komunikasi dan Bisnis. Bandung: Alfabeta.

Rudianto.(2012). Pengantar Akuntansi : Konsep dan Teknik Penyusunan Laporan Keuangan. Jakarta : Erlangga.

Santhi Yuliana Sosiawan. (2012). Pengaruh Kompensasi, Leverage, Ukuran Perusahaan dan Earning Power terhadap Manajemen Laba.Jurnal Riset Akuntansi Keuangan Volume.8, No. 1, Februari 2012.Yogyakarta : Prodi Akuntansi Fakultas Ekonomi dan Bisnis Universitas Kristen Duta Wacana Yogyakarta.

Scott, William R. (2014). Financial Accounting Theory.Canada : Pearson Canada Inc.

Sri Sulistyanto. (2009). Manajemen Laba : Teori dan Model Empiris. Edisi Revisi. Jakarta : Grasindo.

Subramanyam K.R., dan Wild, John J., et.al. (2010). Analisis Laporan Keuangan. Buku 2.Edisi 
10.Jakarta : Salemba Empat.

Sugiarto.(2009). Struktul Modal, Struktur Kepemilikan Perusahaan, Permasalahan Keagenan dan Informasi Asimetri. Yogyakarta : Graham Ilmu.

Sugiyono. (2010). Metode Penelitian Kuantitatif Kualitatif dan $R \& D$. Bandung : Alfabeta. . (2012). Metode Penelitian Kuantitatif Kualitatif dan $R$ \& D. Edisi Revisi.Bandung: Alfabeta. . (2014). Metode Penelitian Bisnis.Bandung : Alfabeta.

Sutojo Siswanto dan Aldrige Edward John.(2009). Good Corporate Governance dan Tata Kelola Perusahaan yang Sehat.Jakarta : Damar Mulia Pustaka.

Theresia Christina Tarigan. (2011).Pengaruh Asimetri Informasi, Corporate Governance dan Ukuran Perusahaan terhadap Praktik Manajemen Laba (Pada Perusahaan Manufaktur yang terdaftar di Bursa Efek Indonesia (BEI).Skripsi.Yogyakarta : Prodi Akuntansi Fakultas Ekonomi dan Bisnis Universitas Pembangunan Nasional Veteran Yogyakarta.

Tim Penyusun. (2014). Pedoman Penyusun Skripsi.Edisi Revisi. Jakarta : Uhamka Press. Website : http://www.idx.comhttp://www.kompas.com. 